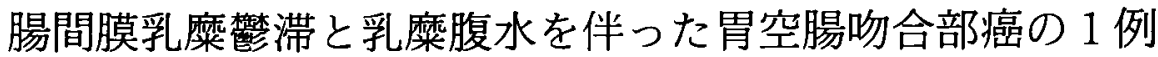
九州大学第 1 外科

$\begin{array}{lllllllll}\text { 渡 } & \text { 辺 } & \text { 保 } & \text { 中幸 } & \text { 中 村 } & \text { 賢二郎 } & \text { 亀 井 隆 史 } \\ \text { 佐 } & \text { 藤 } & & \text { 裕 } & \text { 田 } & \text { 雅 夫 } & & & \end{array}$

術後44年目に発症した乳糜腹水を伴う胃空腸吻合部癌の 1 例を報告する。症例は63歳, 女性. 主訴は心窩部痛で, 胃空腸吻合術は44年前に幽門狭窄症に対して行われていた。 早期癌の術前診断にて開腹したが, 乳糜腹水を伴う癌性腹膜炎で, 空腸間膜根部のリン

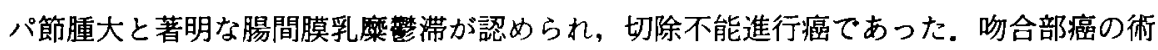
前病期診断は文献的にも困難なことが多く，早期発見のためには長期にわたる定期的な 内視鏡下生検が必要である．また，胃空腸吻合術後はリンパ流の変化を来すため，治㦄 切除可能症例では, 胃と空腸に関わる広範な領域郭清が重要と考えられた。

索引用語：吻合部胃癌，胃空腸吻合，乳糜腹水

\section{緒言}

胃空晹吻合術後 44 年目に吻合部に発生し，小腸間膜 根部リンパ節転移によるリンパ管閉塞のために乳糜腹 水を伴った，切除不能進行癌の 1 例を経験した。胃空 腸吻合術後の胃癌の診断と外科的治療方針に関して文 献的考察䘮加えて報告する.

$$
\text { 症例 }
$$

患者 : 63歳, 女性.

主訴：心窝部痛.

現病歴：1995年 4 月に心窩部痛が出現したため近医 を受診し，上部消化管造影にて胃腸吻合部に腫瘍性病 変を認めた。当院内科に精査入院後, 胃空腸吻合部癌 の診断で同年 7 月 28 日手術目的にて当科に入院となっ た。

既往歴：1951年19歳時, 幽門狭窄症に対して Braun 吻合を加えた結腸前経由の胃空腸吻合術を受けてい た。

家族歴，生活歴：特記すべことなし.

入院時現症: 身長 $150 \mathrm{~cm}$, 体重 $43 \mathrm{~kg}$, 栄養は良好で, 発熱, 負血, 黄㾝を認めずVirchow リンパ節を含む表 在リンパ節は触知しなかった。 上腹部正中に手術創が あり，心窩部に圧痛を認めたが，腫瘤は触れず腹水の 存在も不明であった。直腸指診でもSchnitzler 転移を 疑わせる異常は認めなかった。

1997年 2 月 17 日受付 1997 年 8 月11日採用
入院時検査成績：軽度の貧血と白血球の増多を認め たが，他は正常範囲内であった（表 1 ）。上部消化管透 視では，胃体部大彎側に胃空腸吻合がなされており， その口側に不整形のバリウム斑を認め,ひだの集中と 壁の硬化も伴っていた(図 1)。バリウムの空腸脚への 通過は良好であった。手術操作による影響と考えたが 深部浸潤も否定できなかった. 胃内視鏡検査では, 胃 空腸吻合部の口側に不整形の潰場を認め, 趨壁の集中, 太まりと癒合を伴っていた(図 2 )。また，十二指腸球 部は潰瘍疫痕で著明に変形していた。生検ではGroup V, 印環細胞癌の組織診断であった。その他の部位には局 在病変は認めなかった。逆行性大腸透視では, 横行結 腸に管外性の圧排像を認めたが(図 3)，この時点では Braun吻合を伴う結腸前経由の胃空腸吻合による影

表 1 入院時検査成績

\begin{tabular}{lc|ll}
\hline WBC & $9.710 / \mathrm{mm}^{3}$ & TP & $7.1 \mathrm{~g} / \mathrm{dl}$ \\
$\mathrm{RBC}$ & $336 \times 10^{4} / \mathrm{mm}^{3}$ & Alb & $3.6 \mathrm{~g} / \mathrm{dl}$ \\
$\mathrm{Hb}$ & $11.2 \mathrm{~g} / \mathrm{dl}$ & T.bil & $0.6 \mathrm{mg} / \mathrm{dl}$ \\
$\mathrm{Ht}$ & $33.1 \%$ & GOT & $27 \mathrm{U} / l$ \\
$\mathrm{Plt}$ & $36.3 \times 10^{4} / \mathrm{mm}^{3}$ & GPT & $21 \mathrm{U} / l$ \\
$\mathrm{PT}$ & $11.8 \mathrm{~s}$ & ALP & $226 \mathrm{IU} / l$ \\
APTT & $27.9 \mathrm{~s}$ & Amy & $158 \mathrm{IU} / l$ \\
CRP & $1.0 \mathrm{mg} / \mathrm{dl}$ & $\mathrm{Na}$ & $144 \mathrm{mEq} / l$ \\
CEA & $0.9 \mathrm{ng} / \mathrm{ml}$ & $\mathrm{K}$ & $4.4 \mathrm{mEq} / l$ \\
AFP & $21.5 \mathrm{ng} / \mathrm{ml}$ & $\mathrm{Cl}$ & $107 \mathrm{mEq} / l$ \\
& & $\mathrm{Ca}$ & $8.9 \mathrm{mEq} / /$ \\
\hline
\end{tabular}




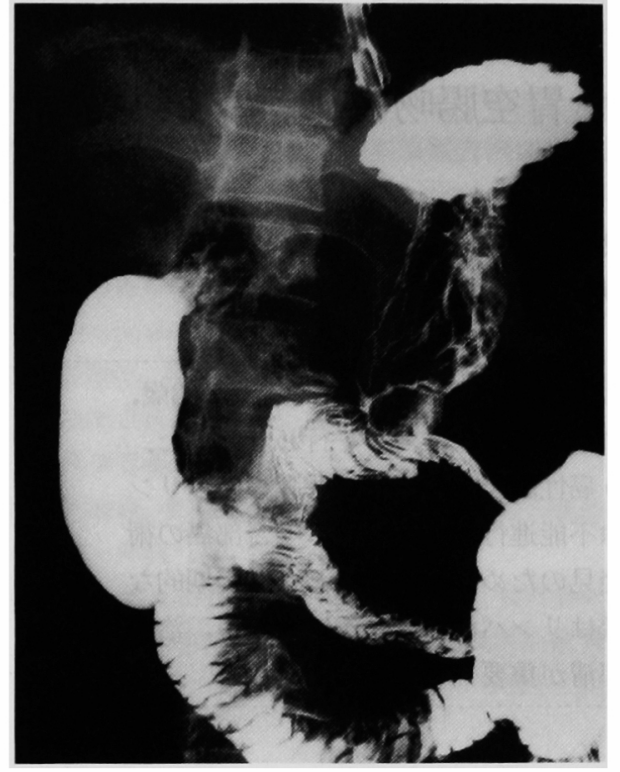

図 1 上部消化管透視：胃体部大彎側に胃空腸吻合部 があり，その口側に不整形のバリウム斑，ひだの集 中, 壁の硬化を認めた.

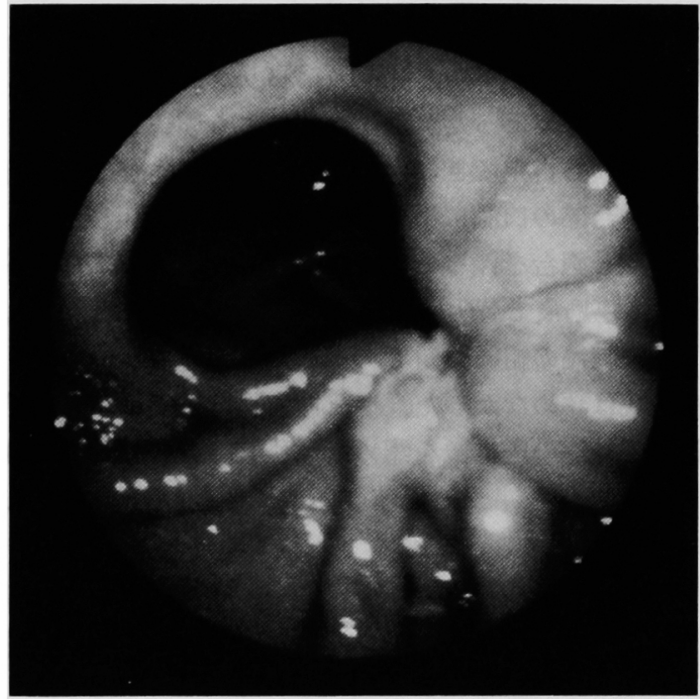

図 2 胃内視鏡検査：胃空腸吻合部口側に白苔が付着 した不整形の潰瘍と周囲の陥凹があり,ひだの集中, 太まり, 癒合を伴っており, 粘膜下層浸潤の IIc + III 型と診断した.

響を一義的に考えた，横行結腸以外の部位には特に局 在病変は認めなかった。上腹部超音波検査では，胃前 庭部の壁肥厚と，胃周囲および腹腔動脈幹周囲に数個

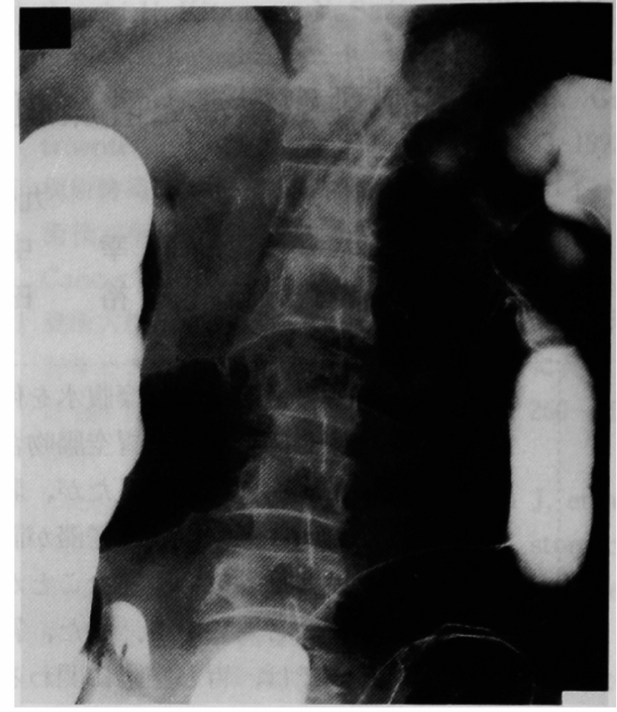

図 3 逆行性大腸造影：横行結腸に管外性の圧排像を 認めた。

のリンパ節腫大を認めたが，はっきりとした腹水や肝 転移は認めなかった。

以上より, 胃空腸吻合部口側に発生した. IIc + III 型 の早期癌との術前診断にて，深達度は粘膜下層までと 考えられ開腹手術を行った。

手術所見：全麻下に上腹部正中切開にて開腹する と, 下腹部を中心に中等量の乳糜腹水の存在を認め, 左横隔膜下, ダグラス窩, 両傍結腸溝に腹膜播種結節 を認めた $\left(\mathrm{P}_{2}\right)$. この腹水の細胞診では Class V（低分 化腺癌）であり，他にも炎症細胞や中皮細胞も含まれ ていた。胃体部大彎後壁に結腸前に持ち上げられた空 腸に続く「胃空腸吻合部」があり，その大彎側後壁口 側を中心に硬い腫瘤を触れ，一部横行結腸に浸潤して いるのが認められた。 なお Braun吻合は開存してい た. 空腸間膜内に多数のリンパ節転移を認め, 特に上 部空腸間膜根部のリンパ節は鶏卵大に腫大しており,

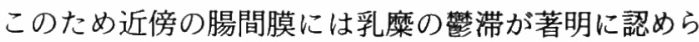
れた(図 4 )。吻合部癌の腸間膜リンパ節転移によるリ ンパ管閉塞のためと考えられた．以上の所見より術中 病期診断は $\mathrm{T}_{4} \mathrm{P}_{2} \mathrm{H}_{0}$ Stage $\mathrm{IV}_{\mathrm{b}}$ であり, 切除不能と判 断した。将来的に癌の浸潤により横行結腸の閉塞を来 すおそれがあるため, 横行結腸 $-\mathrm{S}$ 状結腸吻合術(側々) のみ行って手術を終了した。

術後経過：術後麻痺性の腸閉塞と癌性腹膜炎による 腹水貯留のため腹部膨満が次第に増強し, 腹腔穿刺に 


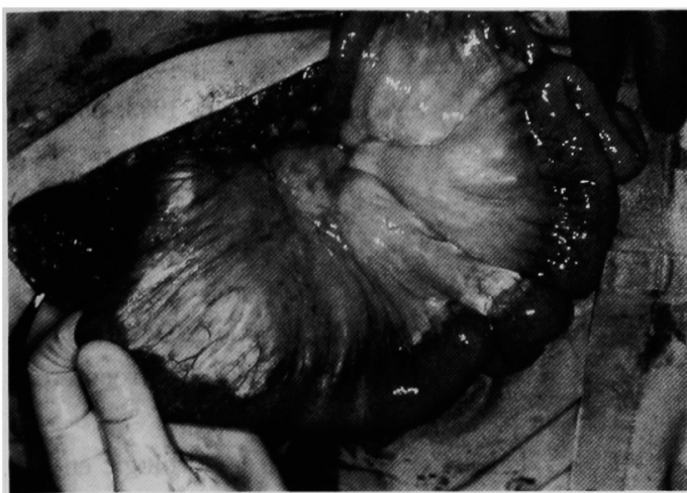

図4手術所見：空腸間膜に多数のリンパ節転移があ り，特に上部空腸間膜根部のリンパ節は鶏卵大に腫 大しており，腸間膜は乳糜のうっ滞が著明だった。

よる腹水排除と OK 432 の腹腔内投与を行ったが, 臨床 症状の改善は認められなかった。さらに腎不全も併発 し, 術後40日目以降は右胸水貯留 (癌性胸膜炎) を認 めるようになり徐々に全身状態が悪化し, 呼吸不全に より術後51日目に永眠された。剖検はされていない.

\section{考察}

幽門狭窄症に対する胃空腸吻合術後 44 年目に発症し た吻合部癌を経験した。早期癌との術前診断で開腹し たところ, 腹膜播種（癌性腹膜炎）と横行結腸への直 接浸潤があり，さらに空腸間膜根部のリンパ節転移に よる，空腸腸間膜乳糜爵滞と乳糜腹水も伴っており切 除不能進行癌と判断した。本疾患の報告例は, 欧米に おいては1926年の Beatson" ${ }^{11}$ 報告例以来比較的多い が，本邦では早期より消化性潰劰に対しては広範胃切 除が行われてきたためか, 本症の報告例は意外と少な い. 発生機序としては, 十二指腸液の胃内への逆流と いう点で「残胃癌」と同様で，恒常的に吻合部へ流入 する十二指腸液中の胆汁酸や膵酵素が発癌のプロモー ターとして考えられている213!

胃空腸吻合術後に発生した胃癌の本邦報告例は，廣

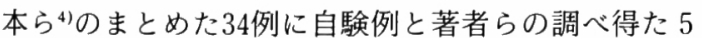
例(5) 8) を加え 39 例，46病変であった．それらの臨床像 は，年齢は25歳から85歳にわたり平均62歳，男女比は $31 ： 7$ で，発症までの期間は胃空腸吻合後11年から56 年にわたり，平均 29 年であった。癌は吻合部または吻 合部近傍に27例，吻合部から離れた部位に 9 例，また 2 例においては胃全体に広がっていた。組織型は低分 化腺癌が15例, 中分化腺癌14例, 高分化腺癌 7 例, 不 明 3 例であった。最終病期診断は早期癌 13 例, 進行癌
表 2 報告例の術前および術後診断

\begin{tabular}{c|c|c|c}
\hline \multicolumn{2}{c|}{} & \multicolumn{2}{|c}{ 術後最終診断 } \\
\cline { 3 - 4 } \multicolumn{2}{c|}{} & 早期癌 & 進行癌 \\
\hline \multirow{2}{*}{$\begin{array}{c}\text { 術前 } \\
\text { 診断 }\end{array}$} & 早期癌 & 10 & 3 \\
\cline { 2 - 4 } & 進行癌 & 1 & 12 \\
\hline
\end{tabular}

20例でそのうち本症のように切除不能で単開腹にお わったものは 3 例であった. 術前術後の診断を検索し 得た 26 症例の, 術前診断と術後最終診断を早期癌と進 行癌とに分類すると(表 2)，4 例においては術前と術 後診断とが異なっており，そのうち 3 例が術前には早 期癌と診断されたのに，最終診断では進行癌であり， いずれも吻合部に生じた病変であり術前病期診断の困 難性を示唆していた。

本症例では, 術前に種々の画像診断から早期癌と診 断したが, 術中予想以上に進行しており最終的には切 除不能の進行癌であった，文献的にも吻合部癌の深達 度診断の難しさがうかがえる．胃透視や内視鏡検査で は造影剤や空気がすぐに吻合空腸脚へ流入するため, 吻合部付近の微細な粘膜の変化を観察することが困難 な場合も多い ${ }^{9)}$. 手術操作による影響と癌の浸潤とを 正しく鑑別することは実際問題としては困難なことが 多い。近年胃癌の深達度診断に有用とされる超音波内 視鏡検査も，吻合部では組織の線維化を伴うため信頼 性が低い ${ }^{10)}$. また, 吻合部は粘膜筋板と粘膜下層とが縫 縮されるため, 粘膜内の癌が比較的早期に固有筋層以 下に浸潤しやすいとされている ${ }^{11}$. それゆえ，胃空腸吻 合を施行した症例では長期にわたって定期的な内視鏡 下生検検查を行うことで，吻合部癌の早期発見に努め るべきであろう121。

本症例では胃空腸吻合によるリンパ流の変化 ${ }^{13)}$ を来 たしたため, 通常型の胃癌の転移としては奇異な空腸 間膜根部リンパ節転移が著明であり，さらに腸間膜の

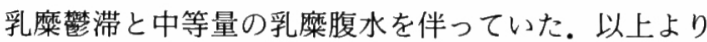
治瘾切除可能症例においては，吻合部切除に加えて胃 と空腸に関わる領域の広範なリンパ節郭清が必要と考 えられた。

\section{結 語}

幽門狭窄に対する胃空腸吻合術後 44 年目に発生し た，癌性腹膜炎と空腸間膜根部リンパ節転移に伴う腸 間膜乳糜樊滞と乳糜腹水を伴った，切除不能な「吻合 部癌」を経験した．報告例に基づく治験を合わせると， 本吻合部癌症例においては長期にわたる定期的内視鏡 
下検査による早期発見が必要である.そして, 治瘾切 除可能な症例においては広範なリンパ節郭清を行うべ きであると考える。

\section{文 献}

1) Beatson GT: Carcinoma of the stomach after gastrojejunostomy. Br Med J 1:15, 1926

2）藤村 隆：十二指腸液胃内逆流によるラット胃発 癌. 胆汁, 脺液の分雔逆流モデルによる検討. 日外 会誌 92: 933-939, 1991

3) Mason RC: Duodenogastric reflux in rat gastric carcinoma. Br J Surg 73: 801-803, 1986

4) 廣本政之, 井野口千秋, 嶋谷邦彦：胃空腸吻合後 40 年してみられた吻合部早期胃癌の 1 例. 日臨外医 会誌 $56: 1849-1855,1995$

5）清久泰司, 西村哲也, 井上洋行：胃腸吻合部癌の 1 例. 日赤医 $38: 16-17,1986$

6）鈴木直人, 粒良幸正, 岩岡秀明他：胃空腸吻合後21 年後を経て発生した吻合部癌の1例。Gastroenterol Endosc 30:2056-2057, 1988

7) Taniguchi $K$, Tanimura $H$, Nakai $T$, et al: Gastric cancer developing 40 years after simple gastrojejunostomy. In: Takahashi $\mathrm{T}$ (ed): Recent advances in management of digestive cancers. Springer-Verlag, Tokyo, 1993, p312314

8）前川透, 斉田 宏, 栄 泰成：胃空腸吻合後33年 後に発生した吻合部腺癌の 1 例. 日消病会誌 91 ： 1963-1966, 1994

9）乾 和郎, 中江良之, 加納潤一：胃空腸吻合後35年 で発生した II c 型早期胃癌の 1 例. Gastroenterol Endosc 26:255-259, 1984

10) Rösch $T$, Classen $M$ : Gastroenterologic endosonography. Thieme, Stuttgart-New York, 1992

11）杉谷 䇴, 稲葉博隆,小山博之：胃空腸吻合後 40 年 を経て発生した吻合部 pm 胃癌の 1 例。日臨外医 会誌 $55: 413-417,1994$

12) Greene FL: Management of gastric remnant carcinoma based on the results of a 15-year endoscopic screening program. Ann Surg 223: 701-706, 1996

13）野口芳一, 今田敏夫, 阿部雅夫：牫胃リンパ溜の臨 床, 実験的研究。日外会誌 $89: 852-861,1988$

\title{
GASTROJEJUNOSTOMAL CARCINOMA WITH MESENTERIC CHYMAL CONGESTION AND CHYMAL ASCITES - REPORT OF A CASE WITH REVIEW OF THE JAPANESE LITERATURE-
}

\author{
Yasuyuki WATANABE, Kenjiro NAKAMURA, Takafumi KAMEI, \\ Hiroshi SATOH and Masao TANAKA \\ First Department of Surgery, Kyushu University Factuly of Medicine
}

A 63-year-old woman who had received gastrojejunostomy for pyloric stenosis 44 years earlier was preoperatively diagnosed by radiology and endoscopy as having stomal early carcinoma. At laparotomy, chymal ascites, peritonitis carcinomatosa, and extensive visceral involvement by the tumor were observed as well as mesenteric chymal congestion caused by metastasis to the mesenteric lymph nodes. The patient died of peritonitis carcinomatosa on the 51st postoperative day. A review of the literature revealed that gastrojejunostomal carcinoma causes difficulty in the preoperative assessment of the tumor involvement, the possibility of mesenteric nodal metastasis as well as perigastric metastasis due to alterations of the lymphatic stream by surgery, and poor curability irrespective of the surgical treatment. 